\title{
UNIA EUROPEJSKA WOBEC NASTĘPSTW ZMIAN KLIMATU W ARKTYCE. MIĘDZY ZAANGAŻOWANIEM A ODRZUCENIEM ${ }^{1}$
}

\author{
Michał Łuszczuk \\ Katedra Krajów Europy Północnej UJK w Kielcach \\ e-mail:mluszczuk@gmail.com
}

\begin{abstract}
Streszczenie: Arktyka staje się regionem o coraz większym ogólnoświatowym znaczeniu, co sprawia, iż Unia Europejska od 2008 roku stara się rozwinąć swoje zaangażowanie w tej części świata. Nasilające się wielowymiarowe następstwa zmian klimatu w połączeniu z nowymi możliwościami rozwoju gospodarczego Arktyki stanowią główne przesłanki przemawiające na rzecz aktywnego, ale też odpowiedzialnego włączenia się Unii Europejskiej wraz z jej arktycznymi partnerami w działania na rzecz zrównoważonego rozwoju regionu. W niniejszym opracowaniu rozważone zostały główne kroki podjęte przez instytucje unijne w kontekście regionu arktycznego w latach 2012-2014. Przeprowadzona analiza wskazuje, iż w obliczu stałego kwestionowania zasadności zaangażowania się Unii Europejskiej w Arktyce przez niektóre państwa (oraz niektórych przedstawicieli arktycznych ludów rdzennych) działania podejmowane przez Unię Europejską należy uznać za niewystarczające, zaś treść najnowszych inicjatyw unijnych nie wydaje się oferować szansy na wzmocnienie roli Unii w regionie Arktyki w najbliższych kilku latach.
\end{abstract}

Słowa kluczowe: Arktyka, Unia Europejska, polityka arktyczna, zmiany klimatu

\section{WSTĘP}

Unia Europejska (UE) z racji swego potencjału oraz politycznych ambicji od początku swego istnienia stara się odgrywać kluczową rolę we współczesnych stosunkach międzynarodowych. Wskazuje na to zarówno dążenie instytucji unijnych do prowadzenia aktywnej polityki w różnych częściach świata, jak też podejmowanie przez nie inicjatyw ukierunkowanych na rozwiązywanie głównych wyzwań globalnych XXI wieku. Interesującym przykładem takiego podejścia UE

1 Badania zostały sfinansowane ze środków Narodowego Centrum Nauki (NCN) przyznanych w ramach finansowania stażu po uzyskaniu stopnia naukowego doktora na podstawie decyzji numer DEC-2012/04/S/HS5/00172. 
jest jej zaangażowanie we współpracę międzynarodową w Arktyce, w regionie, który w ostatniej dekadzie doświadcza wyjątkowo szybkich zmian klimatycznych. Warto w tym miejscu zauważyć, iż zagadnienie to ma szczególne znaczenie także dla polskiej polityki zagranicznej, gdyż aktywne wspieranie rozwoju unijnej polityki arktycznej jest jednym z tzw. filarów polskiego zaangażowania na Dalekiej Północy [Graczyk 2012].

Jak wykazały wcześniejsze badania ${ }^{2}$, podejście UE do regionu arktycznego charakteryzowało się brakiem starannego rozpoznania panującej w nim sytuacji, a szczególnie zachodzących zmian. Instytucje UE dość pochopnie, bez szerszych konsultacji z mieszkańcami regionu i z władzami państw arktycznych, przedstawiły swoje pobieżne diagnozy oraz - wypada to uznać za duży błąd dyplomatyczny - receptę na „poprawę” sytuacji, co zostało odebrane jako lekceważenie, a nawet przejaw paternalizmu. Kontrowersje wśród społeczności międzynarodowej wynikające z tych działań znacząco osłabiły pozycję UE wśród państw arktycznych w kontekście współpracy w regionie Arktyki. Jednocześnie w obliczu wzrostu zainteresowania Arktyką ze strony innych aktorów, np. państw azjatyckich, „straty” UE wydają się jeszcze większe, co pośrednio obniżyło ogólną rolę UE w polityce międzynarodowej. Celem niniejszego artykułu jest dokonanie oceny najnowszych dokumentów unijnych w kontekście dynamicznie rozwijającej się sytuacji międzynarodowej (do roku 2014). Szczególne znaczenie mają tu decyzje dotyczące udziału przedstawicieli oraz ekspertów UE w pracach Rady Arktycznej (RA), które zostały podjęte na szczycie tej organizacji w Kirunie w maju 2013 roku [Arctic Council Secretariat 2013]. Artykuł ma odpowiedzieć na pytania: Czy i jak UE dokonała korekty w zakresie tworzenia i częściowo realizowania swej polityki arktycznej? Jakie to przyniosło rezultaty w kontekście pozycji na Dalekiej Północy?

Artykuł składa się z pięciu części. W części drugiej wskazano podstawowe kwestie dotyczące zakresu i specyfiki podejścia UE do następstw zmian klimatu. W dalszej kolejności przedstawiono wybrane zagadnienia dotyczące zainteresowania Unii Europejskiej obszarami Dalekiej Północy oraz aktualną (tj. lato 2014 roku) formę i zakres zaangażowania Unii we współpracę międzynarodową realizowaną na forum Rady Arktycznej. W czwartej części artykułu przeanalizowano dokumenty przygotowane przez instytucje unijne w latach 2012-2014, stanowiące kolejne elementy unijnej polityki wobec Arktyki. Zaliczono do nich: 1) Wspólny Komunikat Komisji Europejskiej i Wysokiego Przedstawicela do spraw Zagranicznych i Polityki Bezpieczeństwa do Parlamentu Europejskiego i Rady pt.: „Kształtowanie polityki realizowanej przez Unię Europejską w regionie Arktyki: postępy poczynione od 2008 r. i dalsze działania" z 26.06.2012 [ KE, Wysoki Przedstawiciel UE do Spraw Zagranicznych i Polityki Bezpie-

2 Na temat zmian zachodzących w Arktyce zob. Łuszczuk 2013a, Kubiak 2012, Czarny 2014. Na temat zaangażowania UE w Arktyce zob. Głuchowska-Wójcicka 2009, Dośpiał-Borysiak 2011, Łuszczuk 2010a, 2011a, 2011b, 2012. 
czeństwa 2012] (Komunikat); 2) Opinię Europejskiego Komitetu Ekonomiczno-Społecznego w sprawie: „Polityka UE wobec Arktyki w kontekście nowych światowych wyzwań w tym regionie - stanowisko społeczeństwa obywatelskiego" z 17.04.2013 [Europejski Komitet Ekonomiczno-Społeczny 2013] (Opinia); 3) Rezolucję Parlamentu Europejskiego z 12.03.2014 w sprawie strategii UE na rzecz Arktyki [PE 2014a] (Rezolucja); 4) Konkluzje Rady Unii Europejskiej do spraw Zagranicznych w sprawie kształtowania polityki Unii Europejskiej wobec regionu Arktyki z 12.05.2014 [Rada UE, 2014] (Konkluzje). W podsumowaniu artykułu wskazano możliwości dalszego rozwoju podejścia UE do regionu Arktyki w świetle poczynionej analizy.

\section{UNIA EUROPEJSKA WOBEC NASTĘPSTW ZMIAN KLIMATYCZNYCH}

W listopadzie 2012 roku Europejska Agencja Środowiska przedstawiła raport pt. „Climate change, impacts and vulnerability in Europe 2012. An indicator-based report” [EEA 2012], który stanowi kompleksową syntezę wielu badań przeprowadzonych w ostatnich latach w różnych częściach Europy. We wnioskach tej publikacji podkreślono, iż zmiany klimatyczne w Europie stopniowo się nasilają i jakkolwiek ich skala jest zróżnicowana terytorialnie, to generowane przez nie straty coraz mocniej będą wpływać na dobrobyt i bezpieczeństwo społeczeństw europejskich [EEA 2012]. Jedną z możliwych form reakcji w ich obliczu jest podjęcie odpowiednich kroków zmierzających do powstrzymywania procesów intensyfikujących zmianę klimatu (mitigation), jak też równoczesne dostosowywanie się do zmieniających się warunków klimatycznych (adaptation). Niestety oba kierunki działania nie są ani oczywiste (jeżeli chodzi o aktualny i pełny zakres wiedzy na temat zjawisk klimatycznych i ich oddziaływania), ani łatwe (jeśli chodzi o wdrożenie postulowanych rozwiązań w praktykę życia społecznogospodarczego), ani też szybkie [EEA 2013a, 2013b].

Unia Europejska od już blisko czterech dekad opracowuje różnorodne analizy oraz dokumenty polityczne, a także inicjuje działania dotyczące zmian klimatycznych zachodzących w Europie i poza nią [Jordan, Van Asselt, Berkhout, Huitema 2012]. Jak trafnie wskazuje H. Gnaś, podejście to jest wielopłaszczyznowe, gdyż UE zarówno bada uwarunkowania globalnego ocieplenia, promuje wiedzę na temat tego zjawiska wśród europejskiej opinii publicznej, a tym samym kształtuje jego percepcję, jak też podejmuje próby zapobiegania jego przyczynom oraz przeciwdziałania lub łagodzenia jego następstw [Gnaś 2010]. Z uwagi na specyfikę zmian klimatu i ogólnoświatowy charakter następstw zmian klimatycznych (rozumianych jako pochodne zmian zachodzących w klimacie) Unia Europejska angażuje się zarówno na poziomie ogólnoświatowym, jak i w skali europejskiej (w tym też subregionalnej).

W wydanej w 2009 roku białej księdze pt. „Adaptacja do zmian klimatu: europejskie ramy działania” zawarto kompleksowe propozycje Komisji Euro- 
pejskiej dotyczące działań, których zasadniczym celem jest osiągnięcie w UE takiej zdolności adaptacji, by mogła stawić czoło skutkom zmian klimatu. Podkreślono jednocześnie, iż „ze względu na regionalne zróżnicowanie i niejednolitą intensywność skutków zmian klimatu większość środków adaptacyjnych będzie podejmowana na szczeblu krajowym, regionalnym i lokalnym" [KE 2009, s. 7], zaś rolą UE będzie ich wspieranie i wzmacnianie poprzez zintegrowane i skoordynowane podejście na poziomie unijnym. Wskazano, iż ,adaptacja będzie wymagać solidarnego podejścia państw członkowskich UE gwarantującego, że regiony o niekorzystnych warunkach i regiony, w których skutki zmian klimatu są szczególnie odczuwalne, będą w stanie podjąć środki konieczne do adaptacji. Skoordynowane działanie na szczeblu UE będzie ponadto niezbędne w określonych dziedzinach (np. rolnictwo, gospodarka wodna, różnorodność biologiczna, rybołówstwo, sieci energetyczne), które są ściśle powiązane na poziomie UE w ramach jednolitego rynku i wspólnej polityki w poszczególnych dziedzinach" [KE 2009, s. 7]. W przedstawionej zaś w kwietniu 2013 roku „Strategii Unii Europejskiej w zakresie przystosowania się do zmiany klimatu", stanowiącej wynik pierwszego etapu wdrażania ram unijnych działania z 2009 roku, wskazano na konieczność wspierania i stymulowania działań państw członkowskich UE w zakresie adaptacji, stworzenia podstaw do lepszego podejmowania świadomych decyzji w zakresie przystosowania do zmian klimatycznych w nadchodzących latach, a także uodpornienia najważniejszych sektorów gospodarczych i politycznych na skutki zmiany klimatu [KE, 2013].

Jak już wspomniano, Unia Europejska w swej polityce klimatycznej nie ogranicza się do obszaru państw członkowskich, lecz stara się odgrywać ważną (a niekiedy wręcz dominującą) rolę również na arenie międzynarodowej [Groen, Niemann, Oberthür 2013; Bäckstrand, Elgström 2013]. Jej „zewnętrzne” działania w pewnej mierze są dostosowywane do ogólnych założeń i celów polityki klimatycznej UE, jednak bywają ograniczane także przez czynniki gospodarcze, geopolityczne czy też kulturowe. Są również przypadki, kiedy ich realizacja nie jest uwarunkowana wyłącznie aspiracjami i możliwościami instytucji unijnych oraz państw członkowskich, a zależy przede wszystkim od politycznej woli państw trzecich. Takim przypadkiem jest aktywność Unii Europejskiej w regionie Arktyki $^{3}$, w którym zakres zmian klimatycznych w środowisku naturalnym jest najbardziej zaawansowany w skali ogólnoświatowej [Czarny 2014].

${ }^{3}$ W niniejszym opracowaniu stosowana jest definicja pojęcia regionu Arktyki, zgodnie z którą jest to obszar znajdujący się na północ od granicy wyznaczonej kołem podbiegunowym (66 30’40” szerokości geograficznej północnej). Termin „Arktyka” jest stosowany wymiennie z pojęciami: „obszary arktyczne” i „region arktyczny”. Państwa arktyczne to państwa, których pó1nocne obszary terytorium znajdują się w Arktyce: Federacja Rosyjska, Finlandia, Szwecja, Norwegia, Dania (reprezentująca Grenlandię), Islandia, Kanada oraz Stany Zjednoczone. W gronie tym szczególną pozycję zajmują państwa leżące nad brzegiem Oceanu Arktycznego (A5). 


\section{ZAINTERESOWANIE UNII EUROPEJSKIEJ DALEKĄ PÓŁNOCĄ: TŁO I AKTUALNA SYTUACJA FORMALNOPRAWNA}

Wyzwania, które pojawiają się w związku z transformacją dokonującą się za północnym kołem polarnym, od ponad dekady stale zyskują na międzynarodowym znaczeniu ${ }^{4}$. Oznacza to, iż Arktyka za sprawą wielowymiarowych zmian klimatycznych, procesów modernizacji i globalizacji nie jest już postrzegana jako odległa, niezamieszkana „biała pustynia”, lecz coraz powszechniej jest traktowana jako jeden z istotniejszych składników globalnych procesów klimatyczno-ekologicznych [Elverland 2009] oraz jako element światowego ładu politycznego, społecznego, ekonomicznego [AHDR 2004]. Należy przyznać, iż podejścia do oceny charakteru tej transformacji bywają różne, gdyż to, co dla jednych jest wyłącznie obietnicą nowych form aktywności i korzyści (np. wydobycie oraz sprzedaż ropy i gazu pochodzących z szelfu kontynentalnego w Oceanie Arktycznym), przez drugich postrzegane jest głównie jako źródło zagrożeń (np. ekologicznych).

Arktyka na mocy postanowień prawa międzynarodowego, a zwłaszcza Konwencji Narodów Zjednoczonych o prawie morza, jest regionem w znacznej mierze podlegającym wyłącznej jurysdykcji państw, których terytoria położone są na północ od północnego koła podbiegunowego. Z perspektywy tych państw równoważenie zagrożeń i szans, które są obecnie identyfikowane na Dalekiej Północy, ma wyją̧tkowo ważne znaczenie, gdyż skutki ewentualnych błędów czy zaniechań będą zlokalizowane głównie właśnie na ich terytorium. Stąd też dość często niektóre z państw arktycznych wyrażają stanowisko, iż rozwój wydarzeń w Arktyce należy wyłącznie do sfery ich zainteresowania i kompetencji.

Zarazem podkreśla się, iż to, co dzieje się aktualnie w Arktyce, jest głównie efektem procesów zachodzących w innych częściach świata, a także jednocześnie coraz bardziej współkształtuje te procesy. Ta, poniekąd globalna, perspektywa oceny rozwoju sytuacji na Dalekiej Północy jest z kolei właściwa podejściu prezentowanemu przez państwa i organizacje niearktyczne, które jednak z różnych powodów również są żywo zainteresowane zmieniającą się Arktyką. Jak już wspomniano, wśród tych aktorów znajduje się także Unia Europejska, od kilku lat podejmująca działania adresowane specjalnie do Dalekiej Północy (zob. rycina 1), a także starająca się pozyskać dla nich uznanie państw i mieszkańców tego regionu. $\mathrm{Z}$ uwagi na uwarunkowania geograficzne oraz na zakres kompetencji UE w relacjach międzynarodowych wydaje się, iż podstawową ku temu drogą jest udział UE w pracach Rady Arktycznej w charakterze obserwatora.

\footnotetext{
4 Szerzej zob.: Łuszczuk 2013a.
} 


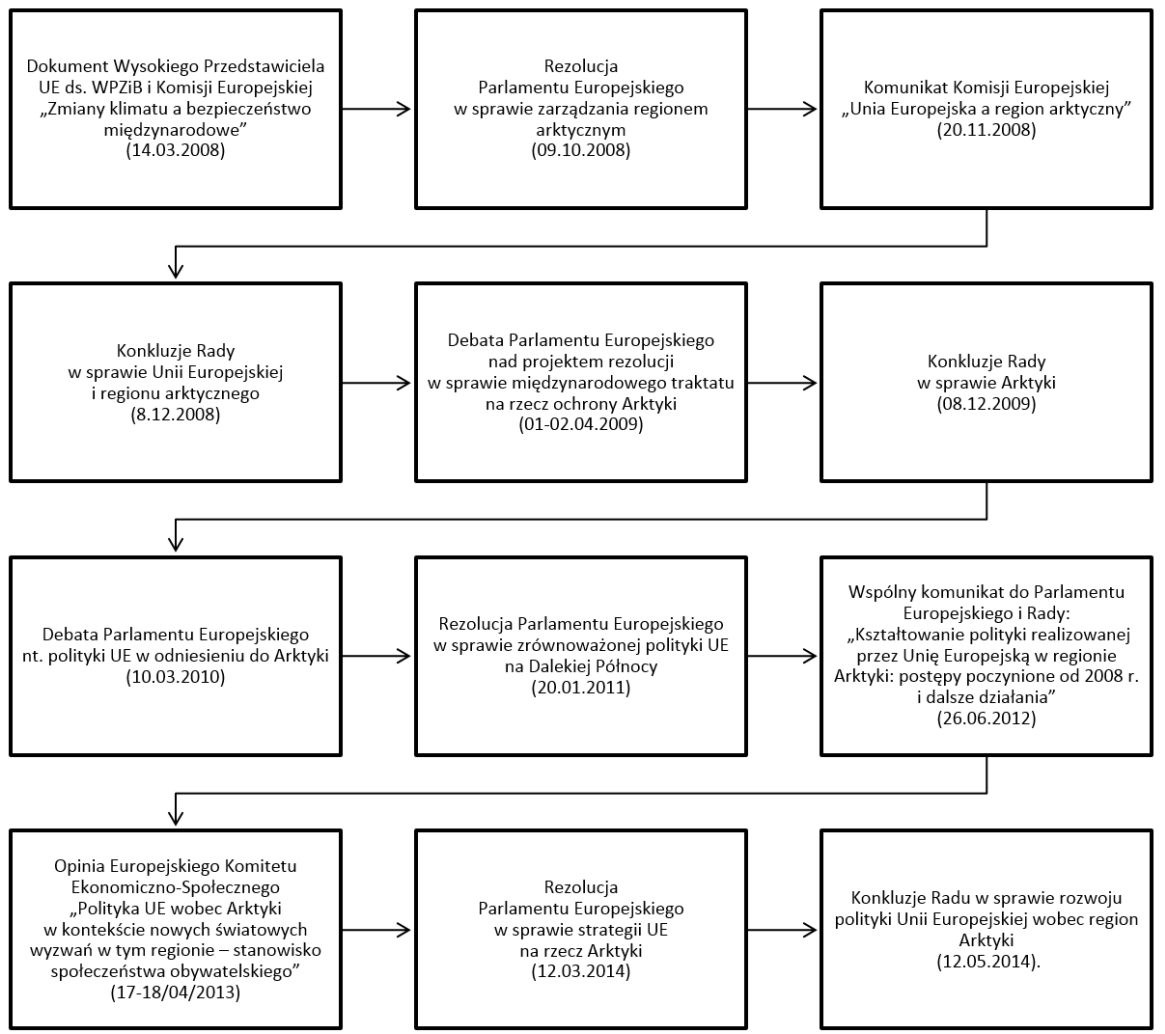

Ryc. 1. Ewolucja stosunku Unii Europejskiej do Arktyki: najważniejsze dokumenty i wydarzenia z lat 2008-2014. Opracowanie własne

Wraz z rozwojem sytuacji w Arktyce na znaczeniu zyskują także platformy regionalnej kooperacji, wśród których główne miejsce zajmuje Rada Arktyczna, będąca głównym forum dialogu i współpracy pomiędzy państwami arktycznymi ${ }^{5}$. Została utworzona w 1996 roku kilka lat po zakończeniu zimnowojennej rywalizacji i zajmuje się głównie problemami dotyczącymi ochrony środowiska oraz adaptacji mieszkańców Arktyki do wyzwań wynikających z procesów modernizacji i globalizacji. Członkami Rady są państwa posiadające terytoria znajdujące się powyżej koła podbiegunowego oraz - na specjalnych prawach - przedstawiciele arktycznych ludów rdzennych. Działania Rady koncentrują się na przygotowywaniu raportów oraz wydawaniu rekomendacji. Kluczową rolę odgrywają w tej pracy grupy robocze współtworzone przez specjalistów z poszczególnych państw zaangażowanych w prace Rady, które zajmują się kilkoma odrębnymi obszarami problemowymi, np. ochroną arktycznej fauny i flory. W pracach Rady Arktycznej biorą również udział tzw. obserwatorzy - są to państwa i organizacje międzynarodowe spoza regionu, które interesują się jego losami i po spełnieniu

\footnotetext{
5 Szerzej na temat Rady Arktycznej zob.: Graczyk 2013.
} 
odpowiednich warunków mogą w określony sposób współuczestniczyć w kształtowaniu jego przyszłości ${ }^{6}$. Do grona tego przez blisko 15 lat należało wyłącznie kilka państw europejskich (m.in. Polska), jednak w 2013 roku państwa arktyczne na swym szczycie w Kirunie zaakceptowały akcesję grupy państw azjatyckich (Chin, Japonii, Indii, Korei Południowej i Singapuru), a także Włoch. W grupie oficjalnie nowo przyjętych obserwatorów zabrakło natomiast Unii Europejskiej, która w 2009 roku złożyła wniosek o status obserwatora.

Pomimo przystąpienia w 1995 roku do Unii Europejskiej Szwecji i Finlandii, które należą do grona państw arktycznych, oraz związków z duńską Grenlandią jako terytorium specjalnym UE (Grenlandia w 1985 roku wystąpiła ze Wspólnot Europejskich), instytucje unijne dopiero w 2008 roku wyraziły swoje nieco zwiększone zainteresowanie rozwojem sytuacji w Arktyce. Być może brak dobrego rozeznania $\mathrm{w}$ sytuacji, a może nadmierna pewność siebie w połączeniu z koniecznością skonfrontowania swych wizji z takimi państwami arktycznymi jak USA, Kanada i Rosja sprawiły, iż bardzo szybko instytucje unijne przekonały się, co to znaczy „stąpać po arktycznym kruchym lodzie”. Wiele z przedstawianych zarówno przez Parlament Europejski, jak i Komisję Europejską opinii, a niekiedy wręcz już prawie gotowych propozycji rozwiązania arktycznych problemów zostało ostro skrytykowanych. Pomimo zaangażowania ekspertów unijnych w prace poszczególnych grup roboczych, a także nakładów Unii na badania w Arktyce (np. w ramach 7 Programu Ramowego było to ok. 200 mln euro) ${ }^{7}$, wniosek Komisji Europejskiej o formalne nadanie jej statusu obserwatora Rady Arktycznej został na spotkaniu ministerialnym RA w Kirunie w maju 2013 roku „zamrożony”.

Niekorzystna dla UE decyzja była wynikiem braku jednomyślności w Radzie Arktycznej co do tego, czy Unia faktycznie respektuje wartości, kulturę i tradycje rdzennych mieszkańców Arktyki i w związku z tym czy spełnia warunki, aby można było nadać jej oficjalnie status obserwatora. Wśród wyjaśnień, które pojawiały się od dłuższego już czasu, najczęściej wskazywano sprzeciw organizacji reprezentujących rdzenne ludy arktycznej Kanady [Keil, Raspotnik 2014]. Miały one pretensję o wprowadzenie w 2009 roku na terytorium UE zakazu handlu produktami z fok - odebrano to jako kwestionowanie tradycyjnego stylu życia plemion inuickich. Kwestia ta, pomimo rozpatrywania jej na forum Trybunału Sprawiedliwości UE, a nawet Światowej Organizacji Handlu (która ostatecznie oddaliła w maju 2014 roku roszczenia strony kanadyjskiej), nadal kładzie się cieniem na relacjach UE i mieszkańców Arktyki ${ }^{8}$ Jednocześnie, co należy

6 Na temat ewolucji statusu instytucji obserwatora w Radzie Arktycznej zob.: Graczyk, Koivurova 2013; Graczyk 2011.

7 Szerzej zob.: Immler 2014.

${ }^{8}$ Na znaczenie tego problemu wskazała także Wysoka Przedstawiciel/Wiceprzewodnicząca Komisji Europejskiej Cathrine Ashton, udzielając odpowiedzi na interpelację eurodeputowanego Adama Bielana (ECR) z 21 maja 2013 roku, dotyczącą pozycji UE w Radzie Arktycznej po szczycie w Kirunie. Wyjaśniła ona mianowicie, iż „wniosek UE o przyznanie statusu obserwatora został przyjęty do rozpatrzenia. Biorąc pod uwagę wynik spotkania ministerialnego Rady Arktycznej w Ki- 
podkreślić, nie blokuje ona zaangażowania specjalistów unijnych w prace Rady Arktycznej w zakresie przewidzianym dla obserwatorów, dzięki czemu można UE uznać obecnie za obserwatora de facto. Możliwe, iż dzięki odnowieniu w 2014 roku strategicznego partnerstwa między Kanadą i UE kanadyjskie weto zostanie wycofane, co jednak nie oznacza, iż wówczas nie pojawią się nowi oponenci oficjalnego włączenia UE do grona obserwatorów Rady Arktycznej. Kwestia zakazu handlu produktami z fok, choć doprowadziła do „odrzucenia” UE w Arktyce, nie jest kluczowym elementem stosunku UE do omawianego regionu. Na czym polega to podejście wyjaśniają najnowsze dokumenty instytucji UE, przywołane w następnej części rozdziału.

\section{ZAANGAŻOWANIE UNII EUROPEJSKIEJ W ARKTYCE: DOKUMENTY Z LAT 2012-2014}

Stosunek Unii Europejskiej oraz jej poszczególnych instytucji do kwestii związanych ze zmianami klimatycznymi w Arktyce oraz do sposobów zarządzania tym regionem ewoluuje. $Z$ poniekąd arbitralnego i pozbawionego odpowiedniej wiedzy na temat specyfiki Dalekiej Północy stopniowo staje się bardziej otwarty na dialog oraz na zrozumienie rzeczywistych potrzeb tego regionu $i$ jego mieszkańców [Østhagen 2013]. Świadczą o tym między innymi dokumenty opracowywane i przedstawiane przez instytucje unijne w latach 2012-2014, których analiza jest celem tego podrozdziału.

\section{WSPÓLNY KOMUNIKAT DO PARLAMENTU EUROPEJSKIEGO I RADY PT.: „KSZTAŁTOWANIE POLITYKI REALIZOWANEJ PRZEZ UNIĘ EUROPEJSKĄ W REGIONIE ARKTYKI: POSTĘPY POCZYNIONE OD 2008 ROKU I DALSZE DZIAŁANIA (JOIN/2012/019 FINAL)}

Komunikat z 26.06.2012 roku stanowi wspólną odpowiedź Komisji Europejskiej oraz Wysokiego Przedstawiciela Unii do spraw zagranicznych i polityki bezpieczeństwa na wezwanie zawarte w konkluzjach spotkania Rady UE [Rada UE 2009], które odbyło się pod koniec listopada 2009 roku. W ramach Komunikatu jego autorzy przedstawili przegląd zaangażowania UE w regionie Arktyki, począwszy od roku $2008^{9}$, jak też zaproponowali kierunki jej dalsze-

runie, Komisja Europejska i ESDZ będzie nadal prowadzić sprawną współpracę z władzami kanadyjskimi mającą na celu rozstrzygnięcie kwestii stanowiącej źródło obaw, mianowicie wyłączenia spod zakazu stosowanego wobec obrotu wyrobami otrzymywanymi z fok w UE" [PE 2014b].

9 Informacje szczegółowe w sprawie postępów osiągniętych w obszarach polityki wymienionych w Komunikacie zostały zawarte także w dwóch dokumentach towarzyszących: 1) dokumencie roboczym służb Komisji „Zestawienie działań w ramach opracowywania polityki Unii Europejskiej w regionie Arktyki”; 2) dokumencie roboczym służb Komisji „Przestrzeń kosmiczna i Arktyka”. 
go zaangażowania w tym regionie. Na wstępie należy odnotować, iż fakt, że publikacja tego dokumentu nastąpiła dopiero w rok po wskazanym przez Radę UE terminie (koniec czerwca 2011 roku), może wskazywać, iż zagadnienia arktyczne - wbrew unijnym deklaracjom - nie należały w tym okresie do spraw szczególnie pilnych dla KE.

Nie stało to jednak na przeszkodzie, by w dokumencie zadeklarować, iż od roku 2008 „UE utrwala swoją rolę kluczowego orędownika regionu Arktyki”, upowszechniając „wiedzę na temat wpływu, jaki UE wywiera na środowisko Arktyki, oraz na temat potencjału umożliwiającego zrównoważony rozwój Arktyki z korzyścią zarówno dla lokalnej ludności Arktyki, jak i dla UE” [KE, Wysoki Przedstawiciel UE do spraw Zagranicznych i Polityki Bezpieczeństwa 2012, s. 1]. W treści Komunikatu wyjaśniono także, iż „[s]zybkie tempo zmian zachodzących w regionie Arktyki stanowi silny argument do zaangażowania UE w ochronę środowiska naturalnego oraz walkę ze zmianami klimatu”, gdyż „Unia Europejska jest organizacją, która w najbardziej zdecydowany sposób opowiada się - na arenie światowej - za intensyfikacją międzynarodowych wysiłków na rzecz walki ze zmianą klimatu poprzez rozwijanie alternatywnych źródeł energii, efektywne gospodarowanie zasobami oraz badania naukowe dotyczące zmiany klimatu" [KE, Wysoki Przedstawiciel UE do spraw Zagranicznych i Polityki Bezpieczeństwa 2012, s. 1]. Dodatkowo podkreślono, iż w związku z tym, że „UE jest głównym odbiorcą zasobów i towarów z regionu Arktyki, to wiele spośród jej działań politycznych i przepisów ma wpływ na podmioty zainteresowane regionem Arktyki” ${ }^{10}$. Mając to uwadze, UE „,pragnie głębiej zaangażować się w kontakty z partnerami w regionie Arktyki, aby zwiększyć swoją wiedzę na temat ich dążeń oraz aby w drodze współpracy podjąć wspólne wyzwania" [KE, Wysoki Przedstawiciel UE do spraw Zagranicznych i Polityki Bezpieczeństwa 2012].

Komisja i Wysoki Przedstawiciel proponują zatem w Komunikacie dalszy rozwój polityki UE wobec Arktyki, wskazując, iż „UE będzie: 1) wspierać badania naukowe i odpowiednio kierować wiedzę, umożliwiając tym samym podejmowanie wyzwań związanych ze zmieniającym się środowiskiem naturalnym oraz zmianami klimatu w Arktyce; 2) działać odpowiedzialnie i dbać o to, aby rozwój gospodarczy w Arktyce oparty był na zrównoważonym wykorzystaniu zasobów i wiedzy eksperckiej dotyczącej środowiska naturalnego; 3) zwiększać swoje konstruktywne zaangażowanie i dialog z państwami regionu Arktyki, ludnością autochtoniczną i innymi partnerami" [KE, Wysoki Przedstawiciel UE do spraw Zagranicznych i Polityki Bezpieczeństwa 2012]. Ogółem w projekcie wymienia się dwadzieścia osiem różnych inicjatyw - projektów działań.

Przy okazji prezentacji Komunikatu Catherine Ashton, Wysoki Przedstawiciel Unii / wiceprzewodnicząca Komisji Europejskiej, stwierdziła: „Poprzez przedstawione dziś działania chcemy pokazać światu, że UE poważnie traktuje swoje zobowiązania wobec regionu arktycznego. Sytuacja w regionie arktycznym

${ }^{10}$ Ibidem. 
sprawia, że nasze prace $\mathrm{w}$ zakresie przeciwdziałania globalnej zmianie klimatu są jeszcze pilniejsze i mają coraz większe znaczenie dla Unii Europejskiej ze względów strategicznych, ekonomicznych i środowiskowych" [KE 2012].

OPINIA EUROPEJSKIEGO KOMITETU EKONOMICZNO-SPOŁECZNEGO W SPRAWIE: „POLITYKA UE WOBEC ARKTYKI W KONTEKŚCIE NOWYCH ŚWIATOWYCH WYZWAŃ W TYM REGIONIE - STANOWISKO SPOŁECZEŃSTWA OBYWATELSKIEGO"

Opinia ta powstała z inicjatywy własnej Europejskiego Komitetu Ekonomiczno-Społecznego, który na sesji plenarnej w dniach 11-12.07.2012 roku (czyli około 2 tygodnie po prezentacji Komunikatu Komisji) postanowił, działając zgodnie z art. 29 ust. 2 swego regulaminu, sporządzić opinię w sprawie: „Polityka UE wobec Arktyki w kontekście nowych światowych wyzwań w tym regionie - stanowisko społeczeństwa obywatelskiego". Sekcja Stosunków Zewnętrznych Komitetu, której powierzono przygotowanie prac Komitetu w tej sprawie, przyjęła swoją propozycję 27.03.2013 roku, zaś ostateczna opinia została zatwierdzona podczas obrad pierwszego dnia 489. sesji plenarnej z 17-18.04.2013 roku. Opinia jest wkładem Komitetu we współpracę arktyczną i politykę UE wobec Arktyki, a także przejawem wzmocnienia jego powiązań ze społeczeństwem obywatelskim w tym regionie. Podstawą do jej sformułowania stało się tzw. wysłuchanie publiczne, które Komitet zorganizował 31.01.2013 roku w północnej Finlandii (Rovaniemi) we współpracy z Centrum Arktycznym Uniwersytetu Lapońskiego ${ }^{11}$.

Opinia składa się z kilku części, które w większości stanowią zbiór ogólnych informacji dotyczących aktualnych przeobrażeń w Arktyce (częśś pt. Konteks, obejmująca prezentację głównych cech charakterystycznych oraz kluczowych wyzwań w regionie Arktyki), zakresu współpracy międzynarodowej w regionie (części pt. Kluczowe podmioty polityczne w regionie Arktyki oraz Wytyczne dla współpracy regionalnej) oraz zaangażowania UE na Dalekiej Północy (część pt. Działalność UE i rozwój polityki wobec regionu Arktyki). Najciekawszą część opinii stanowi zatem część pt. Główne poglądy i zalecenia społeczeństwa obywatelskiego.

Wśród nich znalazło się między innymi zalecenie, by „UE jak najszybciej zakończyła prace nad swoją polityką wobec Arktyki, aby mogła brać udział jako wiarygodny i konstruktywny podmiot i prekursor we współpracy w regionie Arktyki” [Europejski Komitet Ekonomiczno-Społeczny 2013]. Drogą prowadzącą do tego mogłaby być „koncentracja zasobów UE przeznaczonych dla regionu Arktyki w jednym miejscu lub ich efektywna koordynacja, w tym pozycji w budżecie UE dotyczącej regionu Arktyki, aby zapewnić wiarygodne wdrażanie polityki/strategii UE wobec Arktyki" [Europejski Komitet Ekonomiczno-Społeczny, 2013]. Generalnie w tej części opinii wyrażono konieczność zwiększenia zaangażowania UE we

${ }^{11}$ Więcej informacji na temat tego spotkania jest dostępne tutaj: http://www.eesc.europa. $\mathrm{eu} /$ ?i=portal.en.events-and-activities-eu-arctic-policy. 
współpracę w Arktyce na forach czy to Rady Arktycznej, czy to Euro-Arktycznej Rady Morza Barentsa. Podkreślono, iż ,[z]arządzanie w regionie Arktyki należy rozwijać i wdrażać w oparciu o konstruktywną współpracę z państwami z regionu oraz z kluczowymi partnerami. Współpraca i współistnienie w regionie Arktyki powinny w miarę możliwości opierać się na porozumieniach międzynarodowych i współpracy w ramach organizacji międzynarodowych". Jako przyszłościową, interesującą i potrzebną formę współpracy Komitet zaproponował (nawiązując do rezolucji Parlamentu Europejskiego z 20 stycznia 2011 roku w sprawie zrównoważonej polityki UE na Dalekiej Północy) organizację regularnych szczytów arktycznych pod egidą Rady Arktycznej, które umożliwiałyby kluczowym podmiotom zainteresowanym tym regionem współpracą i szansę na omówienie przyszłości regionu oraz osiągnięcie wzajemnego zrozumienia zasad współpracy w regionie.

\section{REZOLUCJA PARLAMENTU EUROPEJSKIEGO Z 12 MARCA 2014 R. W SPRAWIE STRATEGII UE NA RZECZ ARKTYKI (2013/2595(RSP))}

Prezentowana Rezolucja jest trzecią z kolei rezolucją PE (wcześniejsze ogłoszono w latach 2008 i 2011) poświęconą obszarom arktycznym. Jej autorzy przypominają na wstępie, iż „UE ma interesy w Arktyce z racji praw i obowiązków wynikających z prawa międzynarodowego, jej zaangażowania w politykę dotyczącą ochrony środowiska, klimatu i innych dziedzin oraz z racji finansowania i działalności badawczej, a także posiada tam interesy ekonomiczne"12. Zaangażowanie Unii w Arktyce dokonuje się, ,przez uczestnictwo we wspólnej polityce dotyczącej wymiaru północnego prowadzonej z Rosją, Norwegią i Islandią, we współpracy na Morzu Barentsa, w szczególności w ramach Euro-arktycznej Rady Morza Barentsa i Rady Regionu Morza Barentsa, a także w strategicznym partnerstwie z Kanadą, Stanami Zjednoczonymi i Rosją oraz przez jej działalność w ostatnich latach w charakterze aktywnego obserwatora ad hoc w Radzie Arktycznej” [PE 2014a].

W Rezolucji w sposób bardzo precyzyjny wyjaśniono pozycję UE w Radzie Arktycznej, stwierdzając: „Rada Arktyczna podjęła w dniu 15 maja 2013 r. w Kirunie decyzję o »pozytywnym rozpatrzeniu« wniosku UE o przyznanie jej statusu stałego obserwatora”, jednak decyzja ta „zawiera warunek rozwiązania przez UE i Kanadę kwestii zakazu dotyczącego produktów z fok”. Autorzy Rezolucji podkreślają jednak od razu, iż „UE i Kanada są w trakcie rozwiązywania tej kwestii” [PE, 2014a], zaś „UE już pracuje w charakterze ww. stałego obserwatora w Radzie Arktycznej”13. Wyraźnym gestem świadczącym o gotowości

${ }^{12}$ W Rezolucji przypomina się, iż zarówno UE, jak i jej państwa członkowskie posiadają status aktywnych członków w ważnych dla spraw Arktyki gremiach tudzież instrumentów, takich jak Międzynarodowa Organizacja Morska czy Konwencja o różnorodności biologicznej [PE 2014a].

${ }^{13}$ PE podkreślił w tym kontekście konieczność aktywnego uczestnictwa UE we wszystkich istotnych grupach roboczych Rady Arktycznej. Zob.: PE 2014a. 
PE do szukania porozumienia ze stroną kanadyjską jest stwierdzenie, iż „ubolewa z powodu wpływu, jaki rozporządzenie UE w sprawie zakazu dotyczącego produktów z fok miało na część ludności, a w szczególności na tubylczą kulturę i źródła utrzymania" [PE 2014a].

W prezentowanym dokumencie wskazano nie tylko na bliskie związki między UE, jej państwami członkowskimi (i państwami Europejskiego Obszaru Gospodarczego ${ }^{14}$ ) a Arktyką, lecz również na szerszy kontekst międzynarodowy. Podkreślono, iż ,rosnące zainteresowanie regionem arktycznym ze strony podmiotów spoza Arktyki, takich jak Chiny, Japonia, Indie i inne kraje, przeznaczanie przez nie środków finansowych na badania polarne oraz potwierdzenie statusu stałego obserwatora w Radzie Arktycznej przyznanego Korei Południowej, Chinom, Japonii, Indiom i Singapurowi świadczą o coraz większym geopolitycznym zainteresowaniu Arktyką w skali światowej” [PE 2014a].

PE, wyrażając zadowolenie ze wspólnego komunikatu Komisji i Wysokiego Przedstawiciela z czerwca 2012 roku, uznał go za „ważny element struktury zapewniającej stały rozwój polityki UE wobec Arktyki” [PE 2014a]. Jednocześnie Parlament ponowił jednak ,apel o zgodną politykę UE wobec Arktyki oraz o spójną strategię i skonkretyzowany plan działania dotyczący zaangażowania UE w Arktyce, kładący nacisk na zagadnienia społeczno-ekonomiczne i środowiskowe” [PE 2014a]. Dodatkowo, podkreślił „potrzebę ponownego nakierowania działalności instytucji UE na te obszary, istotne ze względu na interesy polityczne, środowiskowe lub gospodarcze UE i jej państw członkowskich" [PE 2014a], jak też „potrzebę uwzględniania interesów UE oraz europejskich państw i regionów arktycznych przy stosowaniu, zmianie i rozwijaniu programów lub polityk UE, które mają lub mogą mieć wpływ na Arktykę, tak aby służyły regionowi Arktyki jako całości" [PE 2014a].

Na zakończenie analizy głównych punktów Rezolucji warto wskazać na powracającą we wszystkich dokumentach Parlamentu Europejskiego (i nie tylko) koncepcję ,powołania unijnego centrum informacyjnego o Arktyce w postaci sieciowej struktury ze stałym biurem w Rovaniemi". Celem tego ośrodka, którego sieciowa formuła była testowana w latach 2013-2014 przez Arctic Centre Uniwersytetu Lapońskiego wspólnie z siecią europejskich centrów doskonałości prowadzących badania obszarów Arktyki (w tym też z Komitetem Badań Polarnych Polskiej Akademii Nauk) byłoby zapewnienie skutecznego dostępu do informacji o Arktyce, prowadzenie dialogu na wszystkich szczeblach oraz orga-

${ }^{14}$ Warto tu odnotować, iż autorzy Rezolucji w kontekście przerwanych w 2013 roku negocjacji o członkostwo Islandii w UE zwrócili się do „Komisji i ESDZ o utrzymanie dobrych stosunków i rozwijanie ściślejszej współpracy z Islandią w obszarach stanowiących przedmiot wspólnego zainteresowania, takich jak rozwój transportu morskiego, rybołówstwo, energia geotermalna oraz środowisko, wykorzystując w pełni istniejące instrumenty i zachęcając do współpracy w Arktyce między podmiotami europejskimi a islandzkimi oraz dbając o to, aby interesy europejskie w tym strategicznym regionie nie ucierpiały" [PE, 2014a]. 
nizowanie komunikacji służącej wykorzystywaniu informacji i wiedzy na rzecz zrównoważonego rozwoju Arktyki w procesach decyzyjnych.

Dokonując oceny Rezolucji, należy podkreślić, iż stanowi ona wyraz kontynuacji zainteresowania Parlamentu Europejskiego kwestiami dotyczącymi Dalekiej Północy. Dość zastanawiające jest jednak użycie już w tytule Rezolucji terminu „strategia”, którego raczej unika się w dokumentach pozostałych instytucji unijnych, a który pojawia się głównie w tytułach dokumentów państw arktycznych. Jak zauważają Raspotnik i Østhagen, przyjęcie tej Rezolucji kilkanaście tygodni przed końcem kadencji Parlamentu wskazuje nie tylko na chęć przypomnienia o ważnej roli PE w procesie kształtowania polityki UE wobec Arktyki, lecz także o tym, iż dla wielu eurodeputowanych zagadnienia dotyczące Dalekiej Północy stanowić mogą ważny punkt w ich programach wyborczych. Dotyczyć to może zagadnień z zakresu ochrony środowiska, rybołówstwa czy rozwoju północnych regionów Szwecji i Finlandii [Raspotnik, Østhagen 2014].

Na początku Konkluzji Rada pozytywnie odniosła się do dokumentów przedłożonych przez KE i Wysokiego Przedstawiciela w 2012 roku oraz przez PE w 2014 roku. Rada, zwracając uwagę na strategiczne znaczenie Arktyki w obliczu narastających dynamicznie zmian klimatycznych, podkreśliła rolę dotychczasowego ${ }^{15}$ i przyszłego zaangażowania Unii we współpracę z ludnością autochtoniczną oraz innymi partnerami z regionu Arktyki. Wskazała szczególnie, iż „UE powinna dążyć do zwiększenia wsparcia ochrony środowiska Arktyki poprzez polityki dotyczące na przykład zmiany klimatu, zanieczyszczeń powietrza [...], różnorodności biologicznej i rybołówstwa" [Rada UE 2014].

Odnosząc się do kwestii udziału Unii Europejskiej w pracach Rady Arktycznej, przedstawiciele państw członkowskich UE potwierdzili „,swoją zgodę i swoje zdecydowane poparcie dla statusu obserwatora UE w Radzie Arktycznej”, zwrócili „uwagę, że UE jest zdecydowana aktywnie działać w charakterze obserwatora w Radzie Arktycznej oraz wnosić wkład w jej działalność”, jak też postulowali wzmocnienie współpracy UE i jej agencji z organami Rady Arktycznej [Rada UE 2014]. Jednocześnie Rada wezwała „Kanadę do wykorzystania obecnej pozytywnej dynamiki w stosunkach UE-Kanada na rzecz rozstrzygnięcia utrzymującej się kwestii, tak aby umożliwić pełne wdrożenie decyzji z Kiruny dotyczącej statusu obserwatora UE w możliwie najkrótszym terminie [...]” [Rada UE 2014].

${ }^{15} \mathrm{~W}$ tym kontekście wskazano na wkład UE we współpracę na rzecz Arktyki poprzez badania naukowe (20 mln EUR rocznie w latach 2007-2013), inwestycje regionalne i transgraniczne (1,14 mld EUR w latach 2007-2013), a także na współpracę z partnerami w dziedzinie ochrony środowiska, transportu, energii i bezpieczeństwa na morzu. 
W Konkluzjach przypomniano, iż „lepsze zrozumienie przemian zachodzących w regionie Arktyki ma zasadnicze znaczenie dla zapewnienia zrównoważonej przyszłości regionu i jego ludności. Rada popiera zatem zwiększenie wkładu UE w realizację badań naukowych dotyczących Arktyki, w tym działań w zakresie monitorowania i obserwacji oraz wymiany i rozpowszechniania informacji o Arktyce" [Rada UE 2014]. Rada zwróciła się do KE z prośbą o rozważenie opcji dotyczących ustanowienia w UE ośrodka informacji o Arktyce, który miałby promować sprawny dostęp do informacji o Arktyce, ułatwiać dialog i informować o kwestiach dotyczących Arktyki.

„W odniesieniu do stopniowego otwierania w nadchodzących latach arktycznych szlaków transoceanicznych dla żeglugi i nawigacji Rada ponownie podkreśliła znaczenie poszanowania prawa międzynarodowego, $\mathrm{w}$ tym zasad wolności żeglugi oraz prawa nieszkodliwego przepływu". Natomiast co do kwestii eksploatacji zasobów energetycznych Rada wyraziła opinię, iż „UE powinna realizować długoterminowe partnerstwa i dialogi polityczne, przyczyniając się do zapewnienia dostępu do surowców i odnawialnych zasobów naturalnych oraz promowania ich bezpiecznego i zrównoważonego wykorzystywania oraz zarządzania nimi” [Rada UE 2014].

W zakończeniu Konkluzji Rada zwróciła się do Komisji „o zapewnienie, by programy dotyczące Arktyki finansowane przez UE na podstawie wieloletnich ram finansowych na lata 2014-2020 spełniały potrzeby społeczności lokalnych dotyczące rozwoju i oferowały lepsze możliwości współpracy i badań naukowych w regionie okołobiegunowym, a także rozwoju gospodarczego Arktyki" [Rada UE 2014]. Rada zwróciła się także do Komisji i do Wysokiego Przedstawiciela, by regularnie informowały ją o postępach w realizacji komunikatu z czerwca 2012 roku i by do grudnia 2015 roku przedstawili wnioski dotyczące dalszego rozwoju zintegrowanej i spójnej polityki arktycznej.

Dokonując oceny przedstawionych Konkluzji, należy na początku podkreślić, iż konkluzje Rady Unii Europejskiej stanowią specyficzny instrument kształtowania polityki arktycznej UE. Podczas gdy rezolucje PE, nie mając charakteru wiążącego, bywają zbiorem wielu opinii, deklaracji czy wręcz życzeń poszczególnych grup politycznych, zaś komunikaty KE stanowią próbę bardziej praktycznego określenia możliwości i wyrażenia ambicji UE wobec współpracy w regionie Arktyki, konkluzje Rady są wyrazem politycznej woli wszystkich państw członkowskich w sprawach arktycznych. O tym, iż nie wszystkie państwa są w tym samym zakresie zainteresowane Arktyką, miała okazję przekonać się choćby polska prezydencja, kiedy próbowała zorganizować jesienią 2011 spotkanie poświęcone tej tematyce ${ }^{16}$. Biorąc to pod uwagę, należy stwierdzić, iż konkluzje przedstawione w 2014 roku nie były i nie mogły być kontrowersyjne. Wydaje się, iż w obecnej sytuacji podsta-

${ }^{16}$ M. Łuszczuk, Arctic Council Observer: The Development and Significance of Poland's Approach towards the Arctic Region, [w:] Ocean Yearbook. Vol. 27, A. Chircop, S. Coffen-Smout, M. McConnell (eds), Boston-Leiden 2013, s. 499. 
wową kwestią, która wciąż na swój sposób „paraliżuje” rozwój polityki UE wobec Arktyki, jest odrzucenie jej zaangażowania przez niektórych partnerów z Dalekiej Północy. Zakładając, iż być może uda się UE osiągnąć porozumienie z Kanadą, trzeba jednak pamiętać o tym, że mogą wówczas pojawić się nowe bariery, tym razem na przykład w formie rosyjskiego weta.

\section{PODSUMOWANIE}

Dokonując podsumowania przedstawionych powyżej postępów w rozwoju polityku UE wobec regionu Arktyki, należy zwrócić uwagę na to, iż nie niosły one ze sobą żadnej istotnej, przełomowej treści. UE, z jednej strony, od wielu już lat jest obecna w regionie Arktyki europejskiej, i choć często są to nieskoordynowane inicjatywy lub projekty, to trudno ich nie dostrzegać (szczególnie w zakresie finansowania badań i monitoringu). $\mathrm{Z}$ drugiej jednak strony próby włączenia się UE w proces politycznego zarządzania regionem na razie napotykają na przeszkody. Obserwując zachowania unijnych urzędników i decydentów, można odnieść wrażenie, iż coraz bardziej są oni tym formalnym „odrzuceniem” zniecierpliwieni. Sytuacja jest tym bardziej interesująca, że pozycja i rola, jaką UE zajmuje w świecie, zderza się na Dalekiej Północy z oporem niepaństwowych uczestników stosunków międzynarodowych w Arktyce. W pewnym zakresie potwierdza to tezę, iż Arktyka stanowi laboratorium stosunków międzynarodowych w środowisku postwestfalskim. Jego hybrydowość uwidacznia się także w formie napięć między poszczególnymi państwami, czego wyrazem są sankcje USA i UE wobec Rosji, które we wrześniu 2014 roku przyjęły także formę zablokowania inwestycji unijnych firm w projekty energetyczne realizowane na obszarach arktycznych Rosji [Staalesen 2014]. Trudno uznać, aby taka forma angażowania się UE w sprawy arktyczne stanowiła szansę na wzmocnienie jej pozycji w Arktyce, podobnie jak nie gwarantuje tego jedynie przyjmowanie kolejnych rezolucji, opinii, komunikatów i konkluzji.

\section{WYKAZ PIŚMIENNICTWA}

1. Arctic Council Secretariat, 2013: Kiruna Declaration, Kiruna, Sweden, 15 May 2013.

2. AHDR, 2004: Arctic Human Development Report, Stefansson Arctic Institute, Akureyri.

3. Bäckstrand K., Elgström O., 2013: The EU's role in climate change negotiations: from leader to 'leadiator', „Journal of European Public Policy”, vol. 20, nr 10, 1369-1386.

4. Czarny R. M., 2014: The Imperative High North: Opportunities and Challenges, Michal Vaško -Vydavatel'stvo, Trnava.

5. Dośpiał-Borysiak K., 2011: Gdy pęka lód. Polityka Unii Europejskiej wobec Arktyki, Analizy Natolińskie, nr 1(49).

6. Elverland E., 2009: The Arctic System, Norwegian Polar Institute, Polarmiljøsenteret, Tromso.

7. EEA, 2012: Climate change, impacts and vulnerability in Europe 2012. An indicator-based report, Copenhagen. 
8. EEA, 2013a: Adaptation in Europe. Addressing risks and opportunities from climate change in the context of socio-economic developments, Copenhagen.

9. EEA, 2013b: Trends and projections in Europe 2013. Tracking progress towards Euro's climate and energy targets until 2020, Copenhagen.

10. Europejski Komitet Ekonomiczno-Społeczny, 2013: Opinia w sprawie: „Polityka UE wobec Arktyki w kontekście nowych światowych wyzwań w tym regionie - stanowisko społeczeństwa obywatelskiego"(2013/C 198/04), Dz. U, UE, C 198, t. 56, 26-33.

11. Głuchowska-Wójcicka M., 2009: Polityka Unii Europejskiej wobec Arktyki, „Colloquium Wydziału Nauk Humanistycznych i Społecznych", vol. 1, 67-74.

12. Gnaś H., 2010: Zmiany klimatyczne - wielopłaszczyznowa adaptacja Unii Europejskiej do wyzwania globalnego, „Teka Komisji Politologii i Stosunków Międzynarodowych - OL PAN”, nr 5, 36-54.

13. Graczyk P., 2013: Rada Arktyczna jako główne forum współpracy w Arktyce, [w:] Arktyka na początku XXI wieku. Między współpracą a rywalizacją, M. Łuszczuk (red.), Wyd. UMCS, 281-315.

14. Graczyk P., Koivurova T., 2013: A new era in the Arctic Council's external relations? Broader consequences of the Nuuk observer rules for Arctic governance, „Polar Record”, vol. 50, 225 236.

15. Graczyk P., 2012: Poland and the Arctic: Between Science and Diplomacy, „Arctic Yearbook”, vol. 1, 139-155.

16. Graczyk P., 2011: Observers in the Arctic Council - Evolution and Prospects, „,The Yearbook of Polar Law" 2011, vol. 3, 575-633.

17. Groen L., Niemann A., Oberthür S., 2013: The EU's Role in International Climate Change Policy-Making: A Global Leader in Decline? In: Global Power Europe, vol. 2: Policies, Actions and Influence of the EU's External Relations. A. Boening, J. Kremer, A. van Loon, Berlin Heidelberg, 37-54.

18. Immler F., 2014: Arctic Research funded by the European Union, Directorate-General for Research and Innovation.

19. Jordan A., van Asselt H., Berkhout F., Huitema D., 2012: Understanding the Paradoxes of Multilevel Governing: Climate Change Policy in the European Union. „Global Environmental Politics", vol. 12 (2), 43-66.

20. Keil K., Raspotnik A., 2014: The European Union's Gateways to the Arctic, „European Foreign Affairs Review", vol. 19, nr 1,101-120.

21. KE, 2009: Biała Księga: Adaptacja do zmian klimatu: europejskie ramy działania, Bruksela. KE, 2012: Komunikat prasowy: Wiedza, odpowiedzialność, zaangażowanie: UE przedstawia zarys polityki wobec Arktyki, Bruksela, 3 lipca 2012.

22. KE, 2013: Strategia UE w zakresie przystosowywania się do zmiany klimatu, Bruksela.

23. KE, Wysoki Przedstawiciel UE do Spraw Zagranicznych i Polityki Bezpieczeństwa, 2012: Wspólny komunikat do Parlamentu Europejskiego i Rady „Kształtowanie polityki realizowanej przez Unię Europejską w regionie Arktyki: postępy poczynione od 2008 r. i dalsze działania”, Bruksela, JOIN(2012) 19 final, 26.6.2012.

24. Kubiak K., 2012: Interesy i spory państw w Arktyce, Wydawnictwo Trio, Warszawa.

25. Łuszczuk M. (red.), 2013a: Arktyka na początku XXI wieku. Między współpracą a rywalizacją, Wydawnictwo UMCS, Lublin.

26. Łuszczuk M., 2013b: Arctic Council Observer: The Development and Significance of Poland's Approach towards the Arctic Region. In: Ocean Yearbook. Vol. 27, A. Chircop, S. Coffen-Smout, M. McConnell (eds), Boston-Leiden 2013, 487-502. 
27. Łuszczuk M., 2012: Polityka arktyczna Unii Europejskiej po Traktacie z Lizbony. W: Unia Europejska po Traktacie z Lizbony. Pierwsze doświadczenia i nowe wyzwania, P. Tosiek (red.), Wydawnictwo UMCS, Lublin, 169-186.

28. Łuszczuk M., 2011: Climate Change in the Arctic and it's Geopolitical Consequences - the Analysis of the European Union Perspective, „The Papers on Global Change”, vol. 16, 87-94.

29. Łuszczuk M., 2010a: Obszary arktyczne w działalności Unii Europejskiej, „Nowa Europa. Przegląd Natoliński”, nr 1(9), 156-182.

30. Łuszczuk M., 2010b: Polityka arktyczna Unii Europejskiej in statu nascendi, „Studia Europejskie", nr 3, 85-110.

31. Østhagen A., 2013: The European Union - An Arctic Actor?, „Journal of Military and Strategic Studies", vol. 15, nr 2, 71-92.

32. PE, 2014a: Rezolucja z dnia 12 marca 2014 r. w sprawie strategii UE na rzecz Arktyki, P7_TA-PROV(2014)0236.

33. PE, 2014b: Pytania pisemne skierowane przez posłów do Parlamentu Europejskiego i odpowiedzi na te pytania udzielone przez instytucję Unii Europejskiej, Dz. U. UE, C41E z 12.2.2014, 325.

34. Rada UE, 2009: Konkluzje Rady dotyczące Arktyki, 2985. posiedzenie Rady do Spraw Zagranicznych, Bruksela, dnia 8 grudnia 2009 r.

35. Rada UE, 2014: Konkluzje w sprawie kształtowania polityki UE wobec regionu Arktyki, Komunikat prasowy z 3312. posiedzenie Rady ds. spraw zagranicznych, Bruksela, 12 maja 2014, $14-16$.

36. Raspotnik A., Østhagen A., 2014: To Svalbard and Beyond - The European Parliament is Back on its Arctic Track, The Arctic Institute 2014 (publikacja on-line: http://www.thearcticinstitute. org/2014/03/to-svalbard-and-beyond-european.html).

37. Staalesen A., 2014: Sanctions target Arctic petro partnerships, BarentsObserver, 12.09.2014 (publikacja on-line: http://barentsobserver.com/en/energy/2014/09/sanctions-target-arctic-petro-partnerships-12-09).

38. Wolska Z., 2010: Polityka Unii Europejskiej wobec zmian klimatycznych, „Studia Europejskie”, nr 3, 59-83.

\title{
EUROPEAN UNION AND THE CLIMATE CHANGE IN THE ARCTIC. BETWEEN ENGAGEMENT AND REJECTION
}

\begin{abstract}
The Arctic is a region of growing global importance, and the European Union has sought to contribute to Arctic cooperation since 2008. Rapid climate change, a major concern and cause of fundamental changes in the Arctic, combined with increased prospects for economic development in the region, require the EU to actively engage with Arctic partners to help address the challenge of sustainable development in a prudent and responsible manner. In this article, the main developments and official documents presented by the EU's institutions between 2012-2014 are scrutinised and reconsidered. It is argued that, in the face of the continuing lack of formal approval by all Arctic Council members, the position of the EU is rather weak and the new documents do not offer compelling arguments for strengthening the EU role in the Arctic region.
\end{abstract}

Key words: Arctic, European Union, arctic policy, climate change 